\title{
Knowledge Mobilization, Collaboration, and Social Innovation: Leveraging Investments in Higher Education
}

\author{
Naomi Nichols \\ The Hospital for Sick Children and York University \\ David J. Phipps \\ York University \\ Johanne Provençal \\ University of Toronto \\ Allyson Hewitt \\ MaRS Discovery District
}

\begin{abstract}
This article is a qualitative literature synthesis in the areas of community-campus collaborations, knowledge mobilization and social innovation. The article aims to be useful to people who work in academic settings, community organizations, public institutions, and government. The authors utilized a purposive sampling methodology to explore the following questions: 1. How can university-based knowledge mobilization leverage investments in higher education research and development (R\&D) through community-campus collaboration and social innovation? 2. What is the role of university-wide knowledge mobilization projects in supporting community-campus connections and ultimately social innovation strategies that contribute to the public good? Our review indicates considerable interplay between community-campus collaborations, knowledge mobilization and social innovation given that knowledge mobilization facilitates - and is facilitated by - collaboration. With sufficient knowledge mobilization, community-campus collaborations stimulate social innovation. The article concludes with recommendations based on our review of the literature.
\end{abstract}

\section{RÉSUMÉ}

Cet article se fonde sur une synthèse littéraire qualitative portant sur les collaborations communautaires/académiques, la mobilisation du savoir et l'innovation sociale. II se veut utile pour toute personne travaillant dans un milieu académique, un organisme communautaire ou une institution publique. Les auteurs ont recours à une méthode d'échantillonnage raisonné pour répondre aux questions suivantes: 1. Comment la mobilisation du savoir universitaire - au moyen de la collaboration communautaire/académique et de l'innovation 


\section{Nicols, Phipps, Provençal, \& Hewitt (2013)}

sociale - peut-elle faire augmenter les investissements en recherche et développement dans l'enseignement supérieur? 2. Comment les projets de mobilisation du savoir universitaire peuvent-ils resserrer les liens entre campus et communauté et, en fin de compte, appuyer des stratégies d'innovation sociale qui contribuent au bien commun? Notre évaluation indique qu'il y a beaucoup d'influences réciproques entre les collaborations communautaires/académiques, la mobilisation du savoir et l'innovation sociale, surtout que la mobilisation du savoir facilite la collaboration et vice versa. En effet, avec une mobilisation du savoir suffisante, les collaborations communautaires/académiques stimulent l'innovation sociale. Cet article se termine par des recommandations provenant de notre analyse documentaire.

Keywords / Mots clés : Social innovation; Knowledge mobilization; Community-academic collaboration; Research; Development / Innovation sociale; Mobilisation du savoir; Collaboration communautaire/académique; Recherche; Développement

\section{INTRODUCTION}

An innovation can be understood as a product, intervention, process, or idea that is "discontinuous from previous practice and yields new pathways for solving acute problems or fulfilling [a] mission" (Rockefeller Foundation, n.d., p. 1). Innovation is widely regarded as central to industry progress and the development of workforce talent. Increasingly, there is recognition that innovation is critical to cultural, environmental, social, and artistic progress as well. With the move from industrial economies to knowledge- and service-based economies, some scholars have observed an "innovation system paradigm shift" (Bullinger, 2006, p. 14, in Howaldt \& Schwarz, 2010, p. 12). Although innovation in science and technology remains critical, there is increasing recognition that social innovation is required to achieve sustainable social and economic impact.

Social innovations require a willingness to "do things differently" (Goldstein, Hazy, \& Silberstang, 2010). Put simply, social innovations are changes that are observed at the level of social practice (Howaldt \& Schwarz, 2010 , p. 21). Social innovations often result from unique combinations of knowledge, practice, techniques, products, and so forth. A social innovation is "a hybridization of existing elements that are combined across boundaries in new ways to yield better solutions, also leaving healthier social relationships in their wake" (Rockefeller Foundation, n.d., p. 1). Optimally, social innovations result in "effective, efficient, sustainable, or just" solutions that benefit society as a whole (Phills, Deiglmeier, \& Miller, 2008).

Social innovations change the systems within which they work. These changes can be felt at a local, regional, or national level. Some examples of social innovation that we have observed include

- Planned Lifetime Advocacy Network (PLAN), a non-governmental organization (NGO) based in Vancouver, B.C., works to benefit the benefit the lives of people with disabilities and their families. PLAN pioneered the Registered Disability Savings Plan (RDSP) to allow parents of a child with a disability to save for their child's future financial security. The RDSP was adopted by the Government of Canada and now benefits children and families across the country.

- The Green Economy Centre is a result of a collaboration between York University and Nottawasaga Futures, a nonprofit community futures agency in rural South Simcoe, Ontario. The Green Economy Centre is an innovative service to help rural businesses adopt green business solutions and help develop a culture of sustainability in the region. 


\section{Nicols, Phipps, Provençal, \& Hewitt (2013)}

- A collaboration with between York University and a community organization led to the development of a Life Skills Mentoring Program at the Youth Emergency Shelter in Peterborough. This is an innovative program that trains and matches mentors from the local college with clients of the shelter. Providing life skills in a one-on-one fashion as opposed to traditional group work reduces the length of stay of youth in crisis and turned the shelter into a social enterprise. The shelter earns revenue by providing life skills mentoring to other agencies, which has generated a new revenue stream of program funding from the provincial government.

This expansive understanding of innovation (e.g., as a process, a product, and an interconnected system of activity) is particularly relevant for higher education research and development (R\&D). As sites of knowledge generation and learning, universities and colleges are well positioned to contribute to innovative discoveries and practices. However, traditional strategies for supporting innovation in institutions of higher education (e.g., technology transfer and commercialization that focus on science, technology, engineering and medicine) do not maximize the social, environmental and economic impact of university research that is not aimed at commercial potential (Mulgan, Tucker, Ali, \& Sanders, 2007). Although there has been significant investment (in Canada and internationally) in technological innovation and commercialization of research, the focus on stimulating social innovation is fairly recent and has not yet begun to sufficiently influence planning and development.

This article synthesizes the literature in the areas of community-campus collaborations, knowledge mobilization, and social innovation. Given the suggestion that innovation can result from the "hybridization of existing elements," we desired an improved understanding of the relationship between community-campus collaborations and social change. We have included the literature on knowledge mobilization in our review because we recognized that collaborators require processes and/or mechanisms that support unique recombinations of existing knowledge and practice (Nichols, Gaetz, \& Phipps, in press).

Community-campus collaborations take multiple forms. An international scan of community-campus interactions identifies four broad categories: 1) relationships between individual faculty members and community organizations that are not supported by institutional structures; 2) centres or institutes that support communitycampus collaboration; 3 ) institutional structures organized within and across academic settings to systematically engage community partners in research; and 4) multi-institutional community-based research partnerships operating regionally, nationally, and internationally (Office of Community-Based Research, 2009). Knowledge mobilization is a similarly multi-faceted concept. For the purposes of this review, we adopt Bennett and Bennett's (2008) conceptualization of knowledge mobilization as "collaborative entanglement" between the users and producers of knowledge.

Our review explores how activities and structures that contribute to mutual learning or knowledge mobilization across community and academic settings (e.g., service-learning opportunities, collaborative research, resource and asset-sharing structures, community-academic colloquia, and knowledge sharing ventures) support collaborative relationships and have the potential to stimulate social change (Pearlman \& Bilodeau, 1999; Roche, 2008; Viswanathan, Ammerman, Eng, Garlehner, Lohr, Griffith, Rhodes, et al., 2004; Office of Community-Based Research, 2009). We are keen to understand how community-campus collaborations facilitated by knowledge mobilization processes - lead to "cross pollination" (Phills et al., 2008, p. 41) between sectors and ultimately enable social innovation. 


\section{Nicols, Phipps, Provençal, \& Hewitt (2013)}

We utilize a purposive sampling methodology (Suri, 2011) to explore the following questions: 1. How can university-based knowledge mobilization leverage investments in higher education R\&D through social innovation and community campus collaboration? 2. What is the role of university-wide knowledge mobilization projects in supporting community-campus connections and ultimately social innovation strategies that contribute to the public good? We examine the literature on collaborations between community members or organizations and post-secondary education institutions (i.e., community-campus collaborations). We investigate the supporting role that knowledge mobilization plays in facilitating community-campus collaborations, and explore how inter-sectoral collaborations lead to change. In so doing, we elucidate a relationship between communitycampus collaborations, knowledge mobilization and social innovation (see Figure 1).

\section{Figure 1: A simplified model of the relationship between community-campus collaboration, knowledge mobilization, and social innovation.}

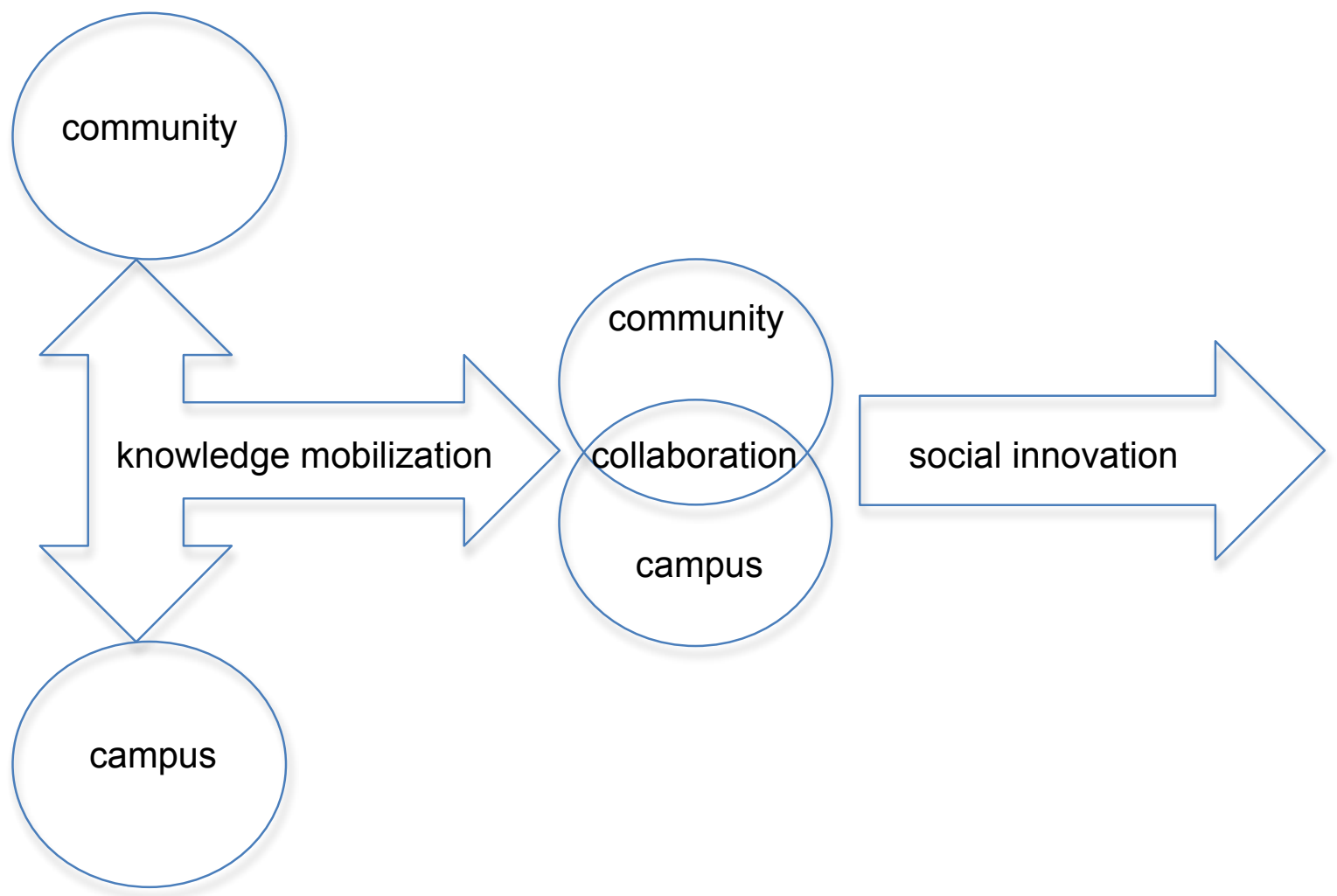

Note: Please see Bennett and Bennett (2008) for a fuller, more complex depiction of the relationship between collaboration, knowledge mobilization, and the production of new knowledge (as cited in Phipps, Jenson, \& Myers, 2012, p. 183).

A synthesis of the literature and an examination of practice indicate that inter-institutional knowledge mobilization personnel, structures, and processes support community-campus knowledge exchange processes and other collaborative activities (e.g., research or service learning). In turn, productive collaborative activities stimulate innovation (see for example, Phipps \& Shapson, 2009). The simplified relationship that we describe between community-campus connections, knowledge mobilization, and social innovation (see Figure 1) does not attempt to capture the other inter-related factors that influence how community-academic research collaborations contribute to innovation and change (Israel, Schultz, Parker, \& Becker, 1998; Nichols, Gaetz, \& 


\section{Nicols, Phipps, Provençal, \& Hewitt (2013)}

Dyck, in press; Nichols et al., submitted). Figure 1 offers a basic illustration of how knowledge mobilization processes facilitate interdisciplinary and inter-sectoral learning and planning in support of social innovation.

This literature review is designed to be of assistance to people who engage in or facilitate community-campus research collaborations and who want to understand how such collaborations contribute to social change. The findings will also be of interest to the research and nonprofit granting bodies, as well as university R\&D Offices that support community-campus collaborations. Specifically, the following two interrelated observations will be useful to readers: first, institutionally supported opportunities for learning across professional, disciplinary, and organizational borders set the stage for social innovation, and second, in order to actualize this potential, collaborators require effective mechanisms or strategies for supporting knowledge mobilization (or learning).

\section{METHODOLOGY}

This article presents the results of a qualitative research synthesis. A qualitative research synthesis is a type of literature review that aims to identify unifying threads, gaps, and critical themes across a body (or bodies) of work. Quantitative and qualitative, unpublished and published primary research sources can be synthesized in this way. Unlike systematic reviews of the literature, which attempt to produce an exhaustive summary of the research in a given area, a qualitative research synthesis explores connections and tensions within a given research area or across research streams. A qualitative research synthesis is useful for exploring conceptual or methodological patterns across diverse bodies of literature. For our purposes - that is, to consider how to leverage investments in higher education R\&D in support of social innovation - a qualitative synthesis is an appropriate approach.

The resources synthesized in this article were collected by three of the article's authors. The synthesis does not reflect an exhaustive review of the literature in the areas of community-campus collaborations, knowledge mobilization, and social innovation; rather, it is a synthesis of our professional libraries and those of our colleagues. Many of the sources reviewed in this article also inform our practice as knowledge mobilizers and researchers. As such, there will be bodies of literature - particularly sources in languages other than English that were not reviewed for this article. This is a shortcoming of our approach; at the onset of the article, therefore, we want to be clear about this limitation.

Our aim was to map key findings from research in our three fields of interest, explore our research questions, and identify key gaps in the three areas of literature. The process of study selection was informed by Arskey and O'Malley's (2005) scoping methodology, as well as Suri's (2011) thinking about purposive sampling in qualitative research syntheses.

Arskey and O'Malley (2005) identify a five-stage scoping study design, which requires an iterative implementation process:

Stage 1: identifying the research question

Stage 2: identifying the relevant studies

Stage 3: study selection

Stage 4: charting the data

Stage 5: collating, summarizing and reporting the results (p. 22)

In our study, we did not progress through these stages in a linear fashion. As we have worked with our three distinct bodies of literature, we have adjusted our guiding research question, sourced additional relevant 


\section{Nicols, Phipps, Provençal, \& Hewitt (2013)}

studies, charted and re-charted the data in order to draw conclusions about the unifying threads in this literature. This article is a final iteration of earlier preliminary syntheses.

As a process, our approach to study selection was non-standardized. We did not use a standard set of inclusion and exclusion criteria, rather we focused instead on selecting a wide variety of primary research sources that would allow us to broadly review our three areas of interest in the context of our over-arching questions. Our goal was to explore a range of primary research in the areas of community-campus collaborations, knowledge mobilization and social innovation. Our use of a purposive sampling search methodology facilitated an in-depth analysis of purposefully selected studies (Suri, 2011). We recognize that there may be other important contributions related to the topics of community-campus collaboration, knowledge mobilization, and social innovation that are not included in our review.

We used a variation of the snowball sampling method, based on the identification of key sources. In order to identify relevant studies to include in the review, we searched electronic library databases (e.g., Social Science Abstract; Web of Science) and specific topically relevant journals (e.g., journals that focus on community engaged scholarship). We reviewed reference lists of key sources and consulted experts in the fields of knowledge mobilization, social innovation, and engaged scholarship. We also utilized an opportunistic sampling methodology, seeking out resources that allowed us to explore our evolving understanding and questions about the relationship between our three areas of interest. We limited our review materials to those materials that were available in English and those produced within the last 15 years (i.e., between 1997 and 2012).

Analysis was guided by a review and coding process. After an initial review of the sources, the authors of this article identified a number of themes to explore in greater detail. At this first stage of analysis, themes remained linked to particular bodies of work (i.e., themes that were identified as pertinent to our understanding of the social innovation literature were different from those identified for the knowledge mobilization literature). Some particularly generative themes included innovation at a systems level; innovation as a process; innovation as a product; institutionalized knowledge mobilization structures; knowledge exchange processes; collaborative processes that facilitate/hinder knowledge exchange; inter-institutional structures that facilitate/hinder knowledge exchange. Once the distinct bodies of literature were coded in this way, we examined relationships between thematic categories. For example, how do institutional structures support inter-institutional/interindividual knowledge exchange, and how does knowledge exchange lead to innovation? Subsequent sections of this article convey the findings from our synthetic review.

\section{Community-campus collaborations}

Strong collaborative relationships (e.g., between post-secondary institutions and the community, broadly conceived [Phipps \& Shapson, 2009] or between government, the nonprofit sector, and business [Phills et al., 2008]) are seen as important drivers of social change. It is widely understood that complex problems - for example, health, social, and environmental problems - are multi-dimensional with inter-dependent causes. Arriving at innovative solutions to these multi-dimensional problems requires multi-dimensional perspectives (see, for example, Emschoff et al., 2007). Inter-systemic, inter-institutional, and inter-disciplinary collaborations are a means for addressing such complex problems, while also maximizing resources, reducing interinstitutional fragmentation and service duplication, creating conceptual and organizational synergy, building community capacity, and engaging people in research (see, for example, Emshoff, Darnell, Darnell, Erickson, Schneider, \& Hudgins, 2007). This section on community-campus collaboration explores the relationship between community-campus collaboration and social innovation with the aim of understanding how these collaborations leverage investments in higher education R \& D through knowledge mobilization. 


\section{Nicols, Phipps, Provençal, \& Hewitt (2013)}

Community-campus collaborations are "collaborations between community organizations and institutions of higher learning for the purpose of achieving an identified social change goal through community engaged scholarship" (Curwood, Munger, Mitchell, MacKeigan, \& Farrar, 2011, p. 3). Engaged scholarship is distinguished by democratic values: partnership, reciprocity, and action (Campbell \& Lassiter, 2010); citing Saltmarsh et al., Campbell and Lassiter (2010) note, it "seeks the public good with the public" (original emphasis). Community-based and participatory research approaches, service learning opportunities, jointproblem solving, collective advocacy, and open forums and debates, can all signal instances of engaged scholarship. For the purposes of this review, the term 'engaged scholarship' references any collaborative activity or interaction that promotes learning and knowledge exchange - or "cross pollination" (Phills et al., 2008, p. 41) -across academic and community settings.

Collaborative processes that shape knowledge exchange for innovation

Notions of reciprocity and inclusivity are important to all collaborative endeavours, but they are considered vital to community-campus collaboration (Campbell \& Lassiter, 2010; Carlton, Whiting, Bradford, Hyjer Dyk, \& Vail 2009; Curwood et al., 2011; Flicker \& Savan, 2006; Israel et al., 1998; Pearce, Pearson, \& Sam, n.d.; Vazquez Jacobus, Baskett, \& Bechstein, 2011). Mutual trust is another pillar of community-academic collaborations (Carlton et al., 2009; Israel et al., 1998; Wright, Williams, Wright, Lieber, Carrasco, \& Gedjeyan, 2011; Vazquez Jacobus et al., 2011), which is established through dialogue and deliberation among stakeholders. In turn, dialogue and deliberation are seen as indicators that the process is guided by democratic values and that public or community participation is a valued asset (Campbell \& Lassiter, 2010; Carlton et al., 2009; Israel et al., 1998; Wright et al., 2011).

Dialogue and deliberation can also signal knowledge exchange. Positive community-campus collaborations recognize and build on the divergent expertise that partners contribute to the collaborative process. Terms like "co-researchers," "co-development," "co-creation," and "knowledge exchange" are used to signal the centrality of the reciprocal partnership in community-campus collaborations.

\section{Collaborative research}

It is common for community-campus collaborations to revolve around research. The use of community-based research (CBR) and community-based participatory research (CBPR) methods are meant to ensure that research is ethical, attentive to the needs of research subjects, includes structures for participation by communities and/or community organizations, improves community health and well-being through action and social change, and is useful outside of academic settings.

Community-campus research collaborations recognize a continuum of participatory strategies for collaborators. The use of multiple methods is one way to encourage interdisciplinary knowledge exchange, and the involvement of a diversity of stakeholders. Many collaborative projects have a mixed methods research design that uses a combination of qualitative and quantitative research strategies. Methodological reflexivity and flexibility are also key facilitators of a collaborative research agenda (Carlton et al., 2009; Nichols, Forthcoming; 2010; Roche, 2008; Israel et al., 1998). In a community-informed research framework, methods should be informed by the purpose of the study and collaborators' desired use for research findings.

Research methods and instruments also need to be culturally appropriate (Flicker, Travers, Guta, McDonald, \& Meagher, 2007; Koné, Sullivan, Senturia, Chrisman, Ciske, \& Krieger, 2000; Kovach, 2005; Wright et al., 2011). Particularly when engaging in participatory community-based research approaches, culturally relevant research tools and methods are essential to an equitable and rigorous research partnership (Koné et al., 2000; Wright et al., 2011). Some studies describe the use of collaborative or team ethnography to facilitate a community- 


\section{Nicols, Phipps, Provençal, \& Hewitt (2013)}

university partnership (Austin, 2003) and community engagement in research (Campbell \& Lassiter, 2010). Collaborative ethnography is a form of qualitative community-based research that uses observation, text analysis, and various forms of interviewing to understand the cultural and social norms of a people or place. Other popular CBR methods include arts-informed research strategies (Sakamoto, Khandor, Chapra, Hendrickson, Maher, Roche, \& Chin, 2008), photo-voice projects (Carlson, Engebretson, \& Chamberlain, 2006), and community mapping (Amsden \& VanWynsberghe, 2005; Burke, O'Campo, Peak, Gielen, McDonell, Trochim, 2005).

\section{Institutional factors that shape collaboration}

Differences in disciplinary culture, paradigm, or institutional values need to be taken into consideration when undertaking inter-institutional collaboration (Carlton et al., 2009; Henderson, MacKay, \& Peterson-Badali, 2010; Lowe \& Phillipson, 2009; Nichols et al. forthcoming). Researchers have identified structural or organizational barriers to collaboration (e.g., Bowen \& Marten, 2005; Curwood et al., 2011; Flicker et al., 2007; Flicker \& Savan, 2006; Lantz, Viruell-Fuentes, Israel, Softley, \& Guzman, 2001) and knowledge mobilization (Cooper \& Levin, 2010) across sectors. The following institutional conditions shape community-campus engagement: the control and distribution of funds; competing institutional demands; funder timelines, reporting requirements, and expectations; ethical review processes; and, university tenure and promotion practices. The emergent or responsive aspects of community-based research mean that there are aspects of a research plan that cannot be articulated prior to beginning fieldwork; this continues to pose challenges for research funders and other stakeholders charged with responsibility for assessing the potential of a research proposal or the rigor of a program of work (Ahmed \& Palermo, 2010; Israel et al., 1998). In order to institutionally support the use of community-based research strategies, research funding timelines and budgets need to acknowledge the value added from collaboration. Understanding how collaborations lead to change (or innovation) will help in this regard.

The literature also identifies key institutional conditions that support community-campus collaboration. Institutional policies and structures that are implemented with an explicit goal to support community-engaged scholarship are essential facilitators of community-engaged research (Israel et al., 1998; Knowledge Mobilization Works, 2010; Roche, 2008). Inter-institutional mechanisms for fund distribution, shared meeting spaces, institutional commitment (e.g., in the form of an official mandate), details of people's workload adjustments, communication strategies, and community access to data management and storage programs need to be addressed prior to initiating a collaboration (Eckerle Curwood et al., 2011).

One valuable institutional mechanism is a community outreach partnership centre or community engagement institute. Whether institutes or centres are community-based (Cherry \& Shefner, 2004) or housed within an academic organization (Hart \& Northmore, 2012; Northmore \& Hart, 2011), they have been found to successfully increase community-campus outreach activities. These centres can also support project management and mediate between the different institutional demands arising from academic and community settings.

Face-to-face or technologically mediated contact is also important (Koné et al., 2000). Communication facilitates and is facilitated by: co-developed collaborative principles, a memorandum of understanding, co-developed operating norms, and/or a statement of ethics are (Campbell \& Lassiter, 2010; Carlton et al., 2009; Isreal et al., 1998; Lantz et al., 2001; Pearlman \& Biladeau, 1999; Wright et al., 2011). Structured and informal opportunities to network and learn together may serve to unsettle people's misconceptions, nurture relationship building, and allow individuals and institutions to establish confidence in one another (Bowen \& Martens, 2005). While relationship building is facilitated by opportunities to learn across difference it also engenders mutual learning as 


\section{Nicols, Phipps, Provençal, \& Hewitt (2013)}

a critical outcome of productive collaborations. Diverse partners bring divergent expertise to the collaborative process that, when mobilised, increases the capacity of the group as a whole (Wright et al., 2011).

When appropriate institutional and interpersonal conditions are in place, community-campus collaborations are sites of knowledge exchange and social innovation (see, for example, Azaroff, Nguyen, Do, Gore, \& GoldsteinGelb, 2011; Krebs, Holden, Williams, Basualdo, \& Spence, 2008; McNall, Reed, Brown, \& Allen, 2009; Nichols, Gaetz, \& Phipps, in press; Phipps, Jenson, \& Myers, 2012; Redmond, Spoth, Shin, Schainker, Greenberg, \& Feinberg, 2009; Spoth, Guyll, Redmond, Greenberg, Feinberg, 2011). Social innovations require mechanisms for working across disciplinary and institutional silos. When inter-institutional knowledge exchange processes are coupled with organizational mandates, bridging structures, and/or strategic plans that privilege collaborative work, community-campus collaborations are well positioned to stimulate interdisciplinary and inter-professional problem solving and exchange.

Supporting collaboration through knowledge mobilization

Institutionalized knowledge mobilization is increasingly common in post secondary education, government, and in non-governmental organizations (Phipps \& Shapson, 2009; Phipps, 2011). Knowledge mobilization supports collaboration when institutional knowledge mobilization units or offices facilitate interdisciplinary, interprofessional, and inter-sectoral links. Knowledge mobilization professionals are "boundary spanning agents" (Weerts \& Sandmann, 2010, p. 704) or "innovation brokers" (Klerkx \& Gildemacher, 2012, p. 221) who facilitate "productive interactions" (Spaappen \& van Drooge, 2011) between diverse stakeholders.

There is a growing literature describing structures, processes, and efforts of knowledge mobilization and related activities (such as knowledge transfer and engaged scholarship) that connect research to decision-makers. Bennet and Bennet (2008), for instance, suggest that knowledge mobilization can increase the impact of social sciences and humanities research on social policy and social services. They describe knowledge mobilization as "collaborative entanglement"; knowledge mobilization allows people "to purposely and consistently develop and support approaches and processes that combine the sources of knowledge and the beneficiaries of that knowledge to interactively move toward a common direction" (Bennett \& Bennett, 2008, p. 48). Bennett and Bennett's description evokes the messy ("entanglement") and social ("collaborative") nature of the relationships that are central to knowledge mobilization processes.

Like those who conceptualize social innovation as a process (e.g., Phills et al., 2008; Phipps, Jenson, \& Meyers, 2012), Nutley, Walter and Davies (2007; see also, Davies, Nutley, \& Walter, 2005; Walter, Nutley, \& Davies, 2003) emphasize social interaction as a central component of effective knowledge mobilization. The co-creation of knowledge supports impactful knowledge exchange processes (Prahalad \& Krishnan, 2008). Gagnon (2011) points out that collaborative knowledge production is associated with research impact. In each of the stages described in the "Knowledge To Action" cycle, strong relationships between researchers, practitioners, policy makers and advocates will maximize the impact of evidence on policy / practice (see for example, Lavis, Robertson, Woodside, McLeod, \& Abelson, 2003). Institutional knowledge mobilization or engagement centres are emerging to facilitate and sustain these relationships (Phipps \& Shapson, 2009; Phipps, 2011).

When opportunities for collaborative entanglement or "productive interactions" (Spaapen \& van Drooge, 2011; Molas-Gallart \& Tang, 2011) lead to the production of new ideas, practices, policies, or products, these unique outcomes can be described as innovations. The collaborative work of academic and non-academic practitioners that is supported by knowledge mobilization activities may result in social innovations that can address a broad spectrum of social issues and needs that cannot be met by technology transfer and commercialization of research alone (Krebs et al., 2008; Phipps \& Shapson, 2009). Knowledge mobilization creates value for the 


\section{Nicols, Phipps, Provençal, \& Hewitt (2013)}

institution as well as for researchers and their decision-maker partners, both in the impact of research used to launch new services or better policies, and in leveraging additional investment of resources (Phipps, 2011).

\section{Social innovation}

Serrat (2010) observes that the turn toward social innovation reflects a growing demand for "good ideas, put into practice, that meet pressing unmet needs and improve people's lives" (p. 1). Our review of the literature suggests that unique combinations of knowledge and practice are facilitated by collaboration and knowledge mobilization across community and academic sectors. The degree to which these collaborative endeavours result in social innovation, however, depends on how the term, social innovation, is defined. Pols and Ville (2009) suggest that a lack of "terminological precision" (p. 878) undermines the impact of interdisciplinary knowledge production. Tabling a definition that is much like Serrat's, Pols and Ville (2009) suggest that any new idea that has the "potential to improve the [macro-] quality or quantity of life is a social innovation" (p. 881). Pols and Ville go on to observe that a social innovation can contribute to profit maximization or not - just like a business innovation can improve the quality or quantity of life for a group of people, or not. While the potential overlap between the terms is substantial, the two terms (i.e., business innovation and social innovation) are not synonymous.

Other scholars define innovation as a process, rather than an outcome (e.g., and idea or a product). In this school of thought, an innovation is defined as "encompassing the entire process -from idea to implementation for new products, services, processes, practices, and policies" (Gardner, Acharya, \& Yach, 2007, p. 1052). In either case, the call for 'social' innovations reflects a widespread recognition that complex and interconnected social problems require a conception of innovation that is not limited to scientific and technological advancement (see Mulgan, Simon, \& Murray, 2008; Howaldt \& Schwarz, 2010; and, Dahrendorf, 2009).

An example of a social innovation in a Canadian context is a new Pension Project that began as a collaboration between a feminist nonprofit Connector Organization that supports joint work between women's community groups and university researchers and a Community Services Unit in a comprehensive public French-language university (for a full description, see Nichols, Gaetz, \& Phipps, in press). People who work in community-based organizations may retire into poverty due to lack of pension plans. The Pension Project aims to support economic stability among people who work in the province's community and nonprofit sectors. The University Community Services Unit provided the research and pension planning expertise, and the community practitioners collectively determined the pension planning strategy and tools, as well as their training and recruitment approach. The creation and conception of the plan by and for representatives of the community sector for the community sector distinguishes this pension plan from others that exist.

Since it's inception in 2008, the Pension Plan has grown from zero to ten million dollars. It has a growing membership of 2,700 employees from 365 different community and women's groups, and it has won awards for innovation from Benefits Canada and the Committee of Labour and Social Economy Community Action. Project participants suggest that it contributes to labour consistencies in the nonprofit sector, allowing them to continue working in the nonprofit sector throughout their careers.

Other examples of social innovations in Canada exist, but many such examples remain undocumented. In "Social Innovation in Canada: An Update" (2009), Goldenberg, Kamoji, Orton, and Williamson indicate that despite Canada's historical contributions to social innovation (in nonprofit, government, and for-profit sectors), the country is lagging behind other Western nations in certain areas. Notably, Canada has not adopted strategic models for public support, funding, and facilitation of social innovation processes. There is a lack of infrastructure and support for innovation on the one hand and a lack of formal analysis of social innovation 


\section{Nicols, Phipps, Provençal, \& Hewitt (2013)}

processes and outcomes on the other. Research in the field of social innovation could usefully inform decisionmaking, problem solving, resource allocation, and knowledge exchange in support of social innovation capacity building (Restler \& Woolis, 2007; Goldenberg et al., 2009; Choi, 2003).

While some individual organizations have created programming streams for social innovation, as an overall field of research and practice, social innovation remains highly fragmented. In turn, this fragmentation has an adverse effect on the extent to which investment in higher education R\&D enables innovation generally and social innovation in particular. A systems level - or ecological - approach to supporting social innovation will require a research framework and tools that account for innovation inputs, processes, outputs, and outcomes across institutional settings. Such tools would also need to be flexible enough to capture the complex "processes of interaction" (Spaapen \& van Drooge, 2011), through which collaboration and knowledge exchange (or mobilization) occur among stakeholders and enable innovation. Any change or impact that results from a social innovation is ultimately also shaped by the people who inform, develop, implement, manage, monitor, and/or otherwise experience an innovation, as well as any number of broader social, political, and institutional conditions. It is thus argued that any conceptualization of a social problem, its potential solution, and the evaluation of any social innovation include multiple indicators of participant characteristics as well as characteristics of the organization (e.g., leadership, composition, size, reinforcement system, etc.) and the community or environment in which it operates [e.g., socioeconomic indicators, geographic culture, relationships to other organizations, etc.] (Hazel \& Onaga, 2003).

To understand how social innovation operates at a systems level, descriptive accounts of the organizations involved, advisory and support services, mentorship strategies, research activities, events, networking approaches, and marketing techniques are needed. Finally, it is important to note that measurement tools and research/evaluation designs should be guided by the same principles of collaboration that underpin innovation (e.g., collaborative study designs, shared terms of reference, distributed leadership/decision making, and mutually beneficial research outcomes). Such a comprehensive account of the inputs, processes, and products of social innovation - particularly at a systems-level - is currently lacking.

Our discussion of social innovation points to various factors that have the potential to facilitate innovation processes at an institutional level. Our review of the literature indicates that systems-integration and research could play a role in the development of an effective, efficient, and coordinated innovation system. In the next section, we explore some policy and practice implications of the results of this synthesis.

\section{DISCUSSION}

Facilitated opportunities for "collaborative entanglement" between community and academic organizations have the potential to stimulate social change. This section of the synthesis identifies the kinds of institutional and social conditions required to effectively leverage resources between communities and higher education institutions to enable social innovation.

Reciprocity is the key to sustaining community-campus collaborations. Effective community-campus collaborations leverage the stability and infrastructural supports of academic institutions and the organizational "nimbleness" of community organizations (Northmore \& Hart, 2011). In order to engender sustained engagement across community and academic settings, there is a need to identify the factors that foster reciprocity and mutual benefit between community and academic partners, as well as their respective institutions (Northmore \& Hart, 2011). 


\section{Nicols, Phipps, Provençal, \& Hewitt (2013)}

It is also important that higher education institutions, community organizations, industry, governments, and funding agencies recognize that equitable and effective collaborations need to be organized, supported, and rewarded differently from traditional, faculty-driven or commercial profit-driven research and development. Building meaningful and effective collaborations between communities and academic institutions requires significant inputs of time and human resources. Sustaining these collaborations requires ongoing attention to, and deliberation about, collaborative processes and outcomes.

Social innovation is fundamentally an "action-oriented, problem-focused approach ... [that] requires a broader view of the processes and structures that contribute to the social problem" (Hazel \& Onaga 2003, p. 287). Knowledge mobilization is fundamental to a productive collaborative process. As a process, knowledge mobilization supports collaborative activities; as an outcome of collaboration, knowledge exchange (i.e., mutual learning) can also be transformative for collaborators. Social innovation is evident in new forms of knowledge exchange, unique collaborative groupings, and ground-breaking applications of new knowledge. Processes of knowledge exchange and innovation can occur iteratively throughout the life cycle of a collaboration; knowledge exchange can also lead to innovation as an essential outcome of collaboration.

The relationship between collaboration, knowledge exchange, and innovation is a central motivation for community-based, collaborative and/or interdisciplinary research. Some have proposed that social scientists should work collaboratively with people who have been most affected by a particular social issue, as a general rule (Hazel \& Onaga, 2003). As people engage in the collective pursuit - or evaluation - of an innovative solution to a complex problem, they share knowledge (Goldstein et al., 2010). In the processes through which knowledge is exchanged, applied, and/or recombined, new knowledge is created (Restler \& Woolis, 2007) and existing social relations are reinterpreted and reimagined (Moulaert \& Ailenei, 2005). In this context, the diverse perspectives and needs of stakeholders are resources that lead to new ideas or strategies (Biggs, Westley, \& Carpenter, 2010).

The benefits of collaboration notwithstanding, productive collaborative processes are not easy to sustain. A number of social, institutional, and political factors shape how collaborations unfold and the social impacts they stimulate. Key facilitating factors at the level of individuals (e.g., leadership, mutuality, communication, and trust) must be coupled with similar supports at the level of institutions (Nichols, Phipps, Gaetz, Tanguay, \& Fisher, forthcoming). Compatible institutional mandates, shared leadership/will, and institutional reciprocity are critical facilitators of community academic collaboration. Of course, collaboration between individuals and between institutions depends on sufficient investments in, and strategic support of, knowledge mobilization, collaboration, and social innovation.

Andrew and Klein (2010) suggest that government has a role to play in this regard. Particularly in the context of inter-sectoral collaboration, government policy is needed to support "the development of strong, and positive, links between sectors" (p. 40). Andrew and Klein argue that social innovation requires institutionalized supports in the areas of capacity building, partnership development, and knowledge transfer, all of which will require public policy frameworks. Traditionally, public policy decision makers have not drawn on the growing body of research about social innovation. Instead, policy decisions have reflected a model of innovation informed by the manufacturing sector, rather than the services management, community/nonprofit, or post secondary education sectors (Osborne \& Brown, 2011). Better links between researchers and policy decision makers can support the creation and implementation of evidence-based social innovation policies and government infrastructure.

That said, we attend to King's (2011) observation that more recent interests in creating and measuring research impact by forging links between university researchers and policy decision makers in the U.K. has the potential 


\section{Nicols, Phipps, Provençal, \& Hewitt (2013)}

to undermine scholars' academic freedoms - that is, their abilities to conduct critical social science research. King also recognizes that the push (from federal funders) for demonstrations of measureable research impact has the potential to undermine basic or "pure" research in favour of research that is applied or oriented to particular policy/practice outcomes. While we do not wade into these debates in this synthesis, we are cognizant of a number of political and ideological tensions shaping the increasing focus on improving the applicability of research knowledge in policy and practice settings.

In part because we are protective of some of the autonomies that post-secondary institutions in Canada share, we believe there are steps that can be taken by universities and colleges, particularly in the areas of knowledge transfer, knowledge mobilization, and knowledge exchange. Goldenberg et al. (2009) note that the creation and implementation of "knowledge mobilization units" in Canadian institutes of post-secondary education serve as central offices, which "connect the wider community with researchers and graduate students on campus ... to link up the university's skills and interests with the needs and aspirations of the public, private and not-for-profit sectors" (p. 26). The facilitation or brokering skills exercised by the people in these institutional centres may prove pivotal to a collaboration's ability to stimulate innovation (Klerkx \& Gildemacher, 2012; Restler \& Woolis, 2007). A strategic and collaborative approach to addressing these limitations - involving government, community organizations, funding agencies, academic organizations, and university infrastructure - is key for leveraging investment in higher education research and development for social innovation as integral to innovation strategies in Canada.

\section{CONCLUSIONS AND POSSIBLE WAYS FORWARD}

In March 2012 the Public Policy Forum released "Leading Innovation: Insights from Canada's Regions." The report suggests that, "collaboration is the lifeblood of innovation" and "fostering these relationships takes more than a simple introduction, it requires consistent networking capacity" (Canada, 2012). Our own literature synthesis supports this view of campus community collaborations as key to social innovation. As shown in Figure 1, knowledge mobilization is a process that helps identify and sustain community-campus collaborations. Post-secondary institutions, governments, research and nonprofit funders, and community organizations will need to collaborate in order to leverage investments in higher education research and development and make social innovation an active component of Canada's innovation strategy.

In the interest of providing clear and actionable next steps for how community-campus collaborations, knowledge mobilization and social innovation can leverage investment in higher education research and development, this article concludes by identifying possible ways forward for research funding, government, community and academic institutions in Canada.

\section{Extending the research arena}

Research is needed that describes the relationship between, and impacts of, community-campus collaborations, knowledge mobilization and social innovation. There is also a need for research that tracks the broader impacts of collaborative work. While university benchmarks and performance indicators have been developed to measure socio-economic and cultural contributions in the U.K., few standardized assessment tools or outcomes-focused evaluations exist (Hart \& Northmore, 2012). Part of the challenge in this is that, in contrast to community development (understood as service to the community), community engagement is a reciprocal relationship based on "non-market forms of reciprocity" (Pearce et al., 2007) and requires more than a quantitative (numeric or economic) evaluation. Hart and Northmore (2011) suggest that the paucity of outcomes-based evaluation of engagement may also be linked to timing. A long-term timescale would be required to capture higher-level institutional outcomes and broader social or community-level impacts. Although some valuable studies have been done, a significant gap in the literature involves assessing the outcomes or 


\section{Nicols, Phipps, Provençal, \& Hewitt (2013)}

impacts of community-campus collaboration. In order to facilitate the production of research that is useful to a diversity of stakeholders, federal research granting bodies, government, and academic institutions should enable longitudinal research on the processes and impacts of community-campus collaborations, knowledge mobilization, and social innovation.

The need for a systematic approach

Although there is much work being undertaken in universities, government, and industry and community organizations that contribute to social innovation and knowledge mobilization, there is a need for a systematic approach to coordinating those efforts and supporting sustained collaborations. Coordination will require committed resources to collaborative planning for social innovation and knowledge mobilization across sectors. Innovative funding mechanisms (e.g., funding that is flows across institutional silos) will be essential to increasing collaboration and coordination in support of inter-institutional planning for knowledge exchange and innovation. In institutions of higher education, institutional supports for social innovation and knowledge mobilization should be integrated into research service offices. Academic institutions should also build on regional and national initiatives to network, share practices and tools and build a pan-Canadian capacity for knowledge mobilization.

\section{A strategic and informed approach}

There is potential for sustained collaborative relationships between universities and other sectors to contribute to social innovation and comprehensively address complex social issues. In any collaborative relationship, there are also significant challenges, however, that must be recognized and addressed. Although universities, government, industry, and community organizations can benefit greatly from collaboration and social innovation, the communities of practice and particular needs in each sector differ from each other. Strategies, policies, programs, and plans to support and sustain social innovation must therefore be adequately informed by an understanding of the differences across sectors as well as by the complexity of the problems that social innovation aims to address. Government, nonprofit sector, and research funders need to recognize the value of social innovation as a missing element in Canada's innovation strategies, and explore possibilities for policies and programs that identify and bridge the needs of academic, industry, and community organizations in regard to social innovation and knowledge mobilization.

\section{ACKNOWLEDGEMENTS}

The authors gratefully acknowledge the support of the Social Sciences and Humanities Research Council of Canada for funding this knowledge synthesis under their funding program "Leveraging public investments in higher education research and development to stimulate innovation."

\section{REFERENCES}

Amsden, J. \& VanWynsberghe, R. (2005). Community mapping as a research tool with youth. Action Research, $3(4), 353-77$.

Ahmed, S. \& Palemo, A. (2010). Community engagement in research: Framework for education and peer review. American Journal of Public Health, 100(8), 1380-89.

Andrew, C. \& Klein, J.L. (2010). Social Innovation: What is it and why is it important to understand it better. Centre de Recherche sur les innovations sociales (Crises). URL: http://www.crises.uqam.cal upload/files/publications/etudes-theoriques/CRISES_ET1003.pdf

Arskey, H. \& O'Malley, L. (2005). Scoping studies: Towards a methodological framework. International Journal of Social Research Methodology, 8(1), 19-32. 


\section{Nicols, Phipps, Provençal, \& Hewitt (2013)}

Austin, D. (2003). Community-based collaborative team ethnography: A community-university-agency partnership. Human Organization, 62(2), 143-152.

Azaroff, L.S., Nguyen, H.M., Do, T., Gore, R., \& Goldstein-Gelb, M. (2011). Results of a community-university partnership to reduce deadly hazards in hardwood floor finishing. Joumal of Community Health, 36, 658-668.

Bennet, A. \& Bennet, D. (2008). Knowledge mobilization in the social sciences and humanities: Moving from research to action. Frost, WV: MQI Press.

Biggs, R., Westley, F.R., \& Carpenter, S.R. (2010). Navigating the back loop: Fostering social innovation and transformation in ecosystem management. Ecology and Society, 15(2), 9.

Bowen, S. \& Martens, P. (2005). Demystifying knowledge translation: learning from the community. Journal of Health Services Research and Policy, 10(4), 203-211.

Bullinger, H-J. (2006). Verdammt zur Innovation. RKW-Magazin, 57(1), $12-14$.

Burke, J., O'Campo, P., Peak, G., Gielen, A., McDonell, K., \& Trochim, W. (2005). An introduction to concept mapping as a participatory public health research method. Qualitative Health Research, 15(10), 1392-1410.

Campbell, E. \& Lassiter, L. (2010). From collaborative ethnography to collaborative pedagogy: Reflections on the other side of Middletown Project and community-university research partnerships. Anthropology \& Education Quarterly, 41(4), 370-385.

Carlson, E., Engebretson, J., \& Chamberlain, R. (2006). Photovoice as a social process of critical consciousness. Qualitative Health Research, 16(6), 836-852.

Carlton, E., Whiting, J., Bradford, K., Hyjer Dyk, P., \& Vail, A. (2009). Defining factors of successful universitycommunity collaborations: An exploration of One Healthy Marriage project. Family Relations, 58(1), 28-40.

Cherry, D. \& Shefner, J. (2004). Addressing barriers to university-community collaboration: Organizing by experts or organizing the experts? Journal of Community Practice, 12(3/4), 219-233.

Choi, J. (2003). How does context influence individual behavior? Multilevel assessment of the implementation of social innovations. Prevention \& Treatment, 6(23).

Cooper, A. \& Levin, B. (2010). Some Canadian contributions to understanding knowledge mobilisation. Evidence and Policy, 6(3), 351-369.

Dahrendorf, R. (2009). Nach der Krise: Zuruck zur protestantischen Ethik? Sechs Anmerkungen. Merkur. Deutsche Zeitschrift fur europäisches Denken, 63(720), 373-381.

Davies, H., Nutley, S., \& Walter, I. (2005). Assessing the impact of social science research: Conceptual methodological and practical issues. Paper presented at the ESRC Symposium on Assessing NonAcademic Impact of Research. School of Management, University of St. Andrews.

Curwood, S., Munger, F., Mitchell, T., MacKeigan, M., \& Farrar, A. (2011). Building effective communityuniversity partnerships: Are universities truly ready? Michigan Journal of Community Service Learning, 17(2), 15-26.

Emshoff, J., Darnell, A., Darnell, D., Erickson, S., Schneider, S., \& Hudgins, R. (2007). Systems change as an outcome and a process in the work of community collaboratives for health. American Journal of Community Psychology, 39, 255-267.

Flicker, S. \& Savan, B. (2006). A snapshot of CBR in Canada. Wellesley Institute.

Flicker, S., Travers, R., Guta, A., McDonald, S., \& Meagher, A. (2007). Ethical dilemmas in community-based participatory research: Recommendations for institutional review boards. Journal of Urban Health: Bulletin of the New York Academy of Medicine, 84(4), 478-493.

Gagnon, M. L. (2011). Moving Knowledge to Action Through Dissemination and Exchange. Journal of Clinical Epidemiology, 64(1), 25-31.

Gardner, C., Acharya, T., \& Yach, D. (2007). Technological and social innovation: A unifying new paradigm for global health. Health Affairs, 26(4), 1052-1061.

Goldenberg, M., Kamoji, W., Orton, L., \& Williamson, M. (2009). Social innovation in Canada: An update. Canadian Policy Research Networks (CPRN). 


\section{Nicols, Phipps, Provençal, \& Hewitt (2013)}

Goldstein, J., Hazy, J., Silberstang, J. (2010). A complexity science model of social innovation in social enterprise. Journal of Social Entrepreneurship, 1(1), 101-125.

Hart, A. \& Northmore, S. (2012). Auditing and evaluating university-community engagement: Lessons from a UK case study. Higher Education Quarterly, 65(1), 34-58.

Hazel, K. \& Onaga, E. (2003). Experimental social innovation and dissemination: The promise and its delivery. American Journal of Community Psychology, 32(3/4), 285-294.

Henderson, J., MacKay, S. \& Peterson-Badali, M. (2010). Interdisciplinary knowledge translation: Lessons learned from a mental health-fire service collaboration. American Journal of Community Psychology, 46(3), 277-288.

Howaldt, J. \& Schwarz, M. (2010). Social innovation: Concepts, research fields and international trends. IMA/ZLW.

Israel, B., Schulz, A., Parker, E. \& Becker, A. (1998). Review of community-based research: Assessing partnership approaches to improve public health. Annual Review of Public Health 19, 173-202.

King, D. (2011). The politics of publicly-funded social research. In John Holmwood (Ed.) A Manifesto for the Public University. New York, NY: Bloomsbury.

Klerkx, L. \& Gildemacher, P. (2012). The role of innovation brokers in agricultural innovation systems. In Agricultural Innovation Systems: An Investment Source Book. Washington DC: The World Bank.

Knowledge Mobilization Works. (2010). Social innovation and social entrepreneurship environmental scan: What works? Unpublished Report prepared for York University and the United Way of York Region.

Koné, A., Sullivan, M., Senturia, K., Chrisman, N., Ciske, S., \& Krieger, J. (2000). Improving collaboration between researchers and communities. Public Health Reports, 115(2/3), 243-248.

Kovach, M. (2005). Emerging from the margins: Indigenous methodologies. In L. Brown \& S. Strega (Eds.), Research as Resistance: Critical, indigenous, and anti-oppressive approaches (1-18). Toronto, ON: Canadian Scholars Press.

Krebs, P., Holden, B., Williams, A., Basualdo, M., \& Spence, C. (2008). A comprehensive action plan information system: A tool for tracking and mapping quality of life action implementation and planning. Social Indicators Research, 85, 127-144.

Lantz, P., Viruell-Fuentes, E., Israel, B., Softley, D. \& Guzman, R. (2001). Can communities and academia work together on public health research? Evaluation results from a community-based participatory research partnership in Detroit. Journal of Urban Health: Bulletin of the New York Academy of Medicine, 78(3), 495-507.

Lavis, J., Robertson, D., Woodside, J., McLeod, C., \& Abelson, J. (2003). How can research organizations more effectively transfer research knowledge to decision makers? The Milbank Quarterly, 81(2), 221-48.

Lowe, P. \& Phillipson, J. (2009). Barriers to research collaboration across disciplines: Scientific paradigms and institutional practises. Environment and Planning, 41, 1171-1184.

McNall, M., Reed, C.S., Brown, R., Allen, A. (2009). Brokering community-university engagement. Innovation and Higher Education, 33, 317-331.

Molas-Gallart, J. \& Tang, P. (2011). Tracing 'productive interactions' to identify social impacts: an example from the social sciences. Research Evaluation, 20(3), 219-226.

Moulaert, F. \& Ailenei, O. (2005). Social economy, third sector and solidarity relations: A conceptual synthesis from history to present. Urban Studies, 42(11), 2037-2053.

Mulgan, G., Tucker, S., Ali, R. \& Sanders, B. (2007). Social innovation: What it is, why it matters and how it can be accelerated (Working paper). Oxford University. URL: http://eureka.bodleian.ox.ac.uk/761/1/Social_ Innovation.pdf [May 1, 2013].

Mulgan, G., Simon, J., \& Murray, R. (2008). How to innovate: The tools for social innovation (Working paper). The Young Foundation. URL: http://youngfoundation.org/publications/how-to-innovate-the-tools-forsocial-innovation/ [May 1, 2013]. 


\section{Nicols, Phipps, Provençal, \& Hewitt (2013)}

Nichols, N., Gaetz, S., \& Dyck, M. (Forthcoming). Both sides now: The social organisation of communityacademic collaboration. In L. Bisaillon (Ed.), The Impact of Policy on Everyday Life: The Policy Stories That People Tell. Netherlands: Springer.

Nichols, N., Gaetz, S., \& Phipps, D. (In press). Generating Social Change through Community Campus Collaboration. Journal of Higher Education Outreach and Engagement.

Nichols, N., Phipps, D., Gaetz, S., Fisher, A., \& Tanguay, N. (forthcoming). Revealing the Complexity of Community-Academic Collaboration. Canadian Journal of Higher Education.

Nichols, N. (Forthcoming) "All my life l've slipped through the cracks:" The Social Coordination of "Youth Work." Toronto, ON: University of Toronto Press.

Nichols, N. (2010). Learning across the borders of community and academy. Pedagogies 5(4), 313-324.

Northmore, S. \& Hart, A. (2011). Sustaining community-university partnerships. Gateways: International Journal of Community Research and Engagement, 4,1-11.

Nutley, S., Walter, I. \& Davies, H. (2007). Using Evidence: How research can inform public services. Bristol, UK: The Policy Press.

Osborne, S. \& Brown, L. (2011). Innovation, public policy and public services delivery in the UK. The word that would be king? Public Administration, 89(4) 1335-1350.

Office of Community-Based Research. (2009). The funding and development of community university research partnerships in Canada: Evidence-based investment in knowledge, engaged scholarship, innovation and action for Canada's future. Office of Community-Based Research, University of Victoria. URL: http://communityresearchcanada.ca/documents/CBRFunding052009.pdf [May 1, 2013].

Pearce, J., Pearson, M., \& Sam., C. (n.d.). The ivory tower and beyond: Bradford University at the heart of its communities. The Bradford University's REAP approach to measuring and evaluating community engagement. URL: http://www.tufts.edu/talloiresnetwork/downloads/REAP_Report_Bradford_U.pdf [May 1, 2013].

Pearlman, S., \& Bilodeau, R. (1999). Academic-community collaboration in teen pregnancy prevention: New roles for professional psychologists. Professional Psychology: Research and Practice, 30(1), 92-98.

Phills, J.A., Deiglmeier, K., \& Miller, D.T. (2008). Rediscovering Social Innovation. Stanford Social Innovation Review, 6(4), 34-43.

Phipps, D. (2011). A report detailing the development of a university-based knowledge mobilization unit that enhances research outreach and engagement. Scholarly Research and Communications, 2(2), 1-13.

Phipps, D., \& Shapson, S. (2009). Knowledge mobilisation builds local research collaborations for social innovation. Evidence \& Policy, 5(3), 211-227.

Phipps, D., Jensen, K., \& Myers, J. (2012) Applying social sciences research for public benefit using knowledge mobilization and social media. In Social Sciences and Humanities - Applications and Theories / Book 1. Ed. Lopez-Varela, M. forthcoming from In Tech.

Pol, E., \& Ville, S. (2009). Social innovation: Buzz word or enduring term? The Journal of Socio-Economics, 38(6), 878-885.

Prahalad, C., \& Krishnan, M. (2008). The New Age of Innovation: Driving Cocreated Value through Global Networks. New York, NY: McGraw-Hill.

Public Policy Forum. (2012). Leading innovation: Insights from Canadian regions. URL: http://www.ppforum.ca /sites/defaultffiles/Leading\%20Innovation\%20-\%20Insights\%20from\%20Canadian\%20Regions_0.pdf [May 1, 2013].

Quarter, J., Mook, L., \& Armstrong, A. (2009). Understanding the Social Economy: A Canadian Perspective. Toronto, ON: University of Toronto Press.

Redmond, C., Spoth, R.L., Shin, C., Schainker, L.M., Greenberg, M.T., \& Feinberg, M. (2009). Long-term protective factor outcomes of evidence-based interventions implemented by community teams through a community-university partnership. Journal of Primary Prevention, 30, 513-530. 


\section{Nicols, Phipps, Provençal, \& Hewitt (2013)}

Restler, S., \& Woolis, D. (2007). Actors and factors: Virtual communities for social innovation. The Electronic Journal of Knowledge Management, 5(1), 89-96.

Viswanathan, M., Ammerman, A., Eng, E., Garlehner, G., Lohr, K., Griffith, D., Rhodes, S., Samuel-Hodge, C., Maty, S., Lux, L., Webb, L., Sutton, S.F., Swinson, T., Jackman, A., \& Whitener, L. (2004). Communitybased participatory research: Assessing the evidence. Agency for Healthcare Research and Quality (AHRQ) Evidence Report Summaries, 99.

Roche, B. (2008). New directions in community-based research. Toronto, ON: The Wellesley Institute.

Rockefeller Foundation. (n.d.). Six factors that boost an organization's capacity to innovate. URL: http://capacitytoinnovate.org/rf_downloads/Rockefeller_6Factors.pdf [March 24, 2013].

Sakamoto, I., Khandor, E., Chapra, A., Hendrickson, T., Maher, J., Roche, B., \& Chin, M. (2008). Homelessness-diverse experiences, common issues, shared solutions: The need for inclusion and accountability. Toronto, ON: Factor-Inwentash Faculty of Social Work, University of Toronto.

Serrat, O. (2010). Sparking Social Innovations. Knowledge Solutions, 79, 1-8.

Spaapen, J., \& van Drooge, L. (2011). Introducing 'productive interactions' in social impact assessment. Research Evaluation, 20(3), 211-218.

Spoth, R., Guyll, M., Redmond, C., Greenberg, M., \& Feinberg, M. (2011). Six-year sustainability of evidencebased intervention implementation quality by community-university partnerships: The PROSPER Study. American Journal of Community Psychology, 48, 412-425.

Suri, Harsh. (2011). Purposeful sampling in qualitative research synthesis. Qualitative Research Journal, 11(2), 63-75.

Vazquez Jacobus, M., Baskett, R., \& Bechstein, C. (2011). Building castles together: A sustainable collaboration as a perpetual work-in-progress. Gateways: International Journal of Community Research and Engagement, 4, 65-82.

Walter, I., Nutley, S., \& Davies, H. (2003). Research Impact: A Cross Sector Review. Research Unit for Research Utilization, University of St. Andrews. URL: http://www.standrews.ac.uk/ ruruweb/pdf/LSDA\% 20literature\%20review\%20final.pdf [May 1, 2013].

Weerts, D.J., \& Sandmann, L.R. (2010). Community engagement and boundary-spanning roles at universities. The Journal of Higher Education, 81(6), 702-727.

Wright, K., Williams, P., Wright, S., Lieber, E., Carrasco, S., \& Gedjeyan, H. (2011). Ties that bind: Creating and sustaining community-academic partnerships. Gateways: International Journal of Community Research and Engagement, 4, 83-90.

\section{ABOUT THE AUTHORS / LES AUTEURS}

Naomi Nichols, Ph.D., is Applied Scientist, About Kids Health, The Hospital for Sick Children Email: naomi.nichols@sickkids.ca and Research Associate, York University; Email: naomi_nichols@edu.yorku.ca

David J. Phipps, Ph.D., MBA, is Executive Director, Research \& Innovation Services, York University Email: dphipps@yorku.ca

Johanne Provençal, Ph.D. is Acting Director, Strategic Initiatives, Office of the Vice-President, Research and Innovation, University of Toronto. Email: johanne.provencal@utoronto.ca

Allyson Hewitt is Director, Social Entrepreneurship, and Director, SiG@MaRS MaRS Discovery District. Email: ahewitt@marsdd.com 